Biogeosciences Discuss., doi:10.5194/bg-2016-376, 2016

Manuscript under review for journal Biogeosciences

Published: 16 September 2016

(c) Author(s) 2016. CC-BY 3.0 License.

\title{
Relating historical vegetation cover to aridity index patterns in the greater desert region of northern China: Implications to planned and existing restoration projects
}

Yanying Shao ${ }^{1}$, Yuqing Zhang ${ }^{1,2}$, Xiuqin $\mathrm{Wu}^{1,3} *$, Charles P.-A. Bourque ${ }^{1,4}$, Jutao Zhang ${ }^{1}$, Shugao Qin ${ }^{1,2}$, 5 and $\mathrm{Bin} \mathrm{Wu}^{1,2}$

${ }^{1}$ Yanchi Research Station, School of Soil and Water Conservation, Beijing Forestry University, Beijing 100083, PR China

${ }^{2}$ Key Laboratory of State Forestry Administration on Soil and Water Conservation, Beijing Forestry University, Beijing 100083, PR China

${ }^{3}$ Engineering Research Center of Forestry Ecological Engineering, Ministry of Education, Beijing Forestry University, Beijing

10 100083, PR China

${ }^{4}$ Faculty of Forestry and Environmental Management, University of New Brunswick, New Brunswick E3B 5AS, Canada

Correspondence to: Xiuqin Wu (wuxq@bjfu.edu.cn)

Abstract. Desert regions of northern China have always been the most severely affected by climate change, especially in terms of their ecological integrity and social sustainable development. Assessments of dryness in both space and time are central to

15 the development of adaptation strategies to climate change. Earlier studies have identified long-term patterns of dryness in northern China, but these studies have usually been of limited value to land-management planning as they ignore local-toregional-scale climate features. To identify potential cause-and-effect relationship between aridity and vegetation cover, changes in aridity index (AI) and vegetation cover were tracked with the assistance of a chronological series of surfaces based on the mapping of AI and normalized difference vegetation index (NDVI) and convergent cross mapping. By tracking regional-

20 scale variation in precipitation, air temperature, AI from 1961-2013 (53 years), and vegetation cover dynamics from 19822013 (32 years), we show that precipitation increased in approximately $70 \%$ of the greater desert region, including in the Ulanbuh, Tengger, Badain Jaran, Qaidam, Kumtag, Gurbantunggut, and Taklimakan Deserts. This increase was statistically strongest for the Gurbantunggut $(p<0.01)$ and Taklimakan Deserts $(p<0.1)$. Unsurprisingly, air temperature rose in nearly all deserts $(p<0.01)$ at approximately 2.5 times greater than the global rate. Changes in AI was analogous to that of precipitation (low AI, denoting hyperarid conditions), except for the Tengger Desert. Increasing AI (i.e., wetting) was statistically strongest for the Gurbantunggut $(p<0.01)$, Qaidam $(p<0.05)$, and Taklimakan Deserts $(p<0.05)$. Vegetation growth largely improved in oases of the western desert region and Mu Us Desert over the 1982-2013 period ( $p<0.1)$. For the most part, aridity had a moderate control on NDVI $(p<0.05)$, with no indication of vegetation feedback. The wetting trend observed in the western desert region (increasing AI) improved ecological conditions of the region by increasing NDVI,

30 particularly in the region's oases. In contrast, continued drying in the eastern desert regions (decreasing AI) had caused NDVI to decrease. Future planning of new restoration projects should ideally take into account drying/wetting trends currently being observed in northern China. 
Biogeosciences Discuss., doi:10.5194/bg-2016-376, 2016

Manuscript under review for journal Biogeosciences

Published: 16 September 2016

(c) Author(s) 2016. CC-BY 3.0 License.

\section{Introduction}

In recent decades, countless studies have demonstrated the indisputable fact of climate change (IPCC, 2013) and its impacts on water resources (Raghavan et al., 2012; Deng et al., 2015; Pumo et al., 2016), ecological environment (Chen et al., 2013; Yang et al., 2015), human settlement (Dumenu and Obeng, 2016), and human health (Wu et al., 2016; Moore et al., 2008;

5 Abaya et al., 2011). Continued global climate change in desert regions of the world may have a profound impact by accelerating hydrological processes and increasing the unpredictability of related hydrometeorological variables (Gan, 2000; Ma et al., 2004; Jentsch and Beierkuhnlein, 2008), leading to a re-shaping of desert-dryness patterns.

Desert regions of northern $(\mathrm{N})$ China cover nearly one-fifth of the country's land base. Drylands have always been the most severely affected by changes in climate (Fullen and Mitchell, 1994; Liu and Diamond, 2005; Wang et al., 2013). Levels of

10 dryness are closely related to desertification and their assessment are fundamental to the development of adaptation strategies. Therefore, an understanding of drying and wetting conditions and their relationship to climate change is vital for the sustainable development of fragile desert environments.

Prior to the 1970's, greater amounts of precipitation fell in the Inner Mongolia region and Xinjiang region; however, since the 1980's, precipitation has decreased by 15-40 and 0-10 $\mathrm{mm} \mathrm{yr}^{-1}$ in the Inner Mongolian Plateau and southern Xinjiang 15 province, respectively (Xu et al., 2010). Li et al. (2013) reported that precipitation had increased 10.2, 6.3, and $0.9 \mathrm{~mm} 10-\mathrm{yr}$ ${ }^{1}$ in the last 50 years in the mountains, oases, and deserts of northwest (NW) China. In general, precipitation in NW China increased $0.61 \mathrm{~mm} \mathrm{yr}^{-1}(p<0.01$ ) during the 1960-2010 period (Li et al., 2016). From 1948-2008, drylands in N China had expanded with their boundaries extending eastward over to NE China by about $2^{\circ}$ of longitude and about $1^{\circ}$ of latitude to the south along the middle-to-lower reaches of the Yellow River (Li et al., 2015). Other studies have indicated a wetting trend in

20 N China (Wang et al., 2007; Huo et al., 2013).

Earlier studies addressing the variation and long-term patterns of aridity in China, usually overlooking local-to-regionalscale features, preclude them from being used in ecological restoration projects because of their usually coarse spatial resolutions. Precipitation, air temperature, and aridity patterns over large areas vary in both space and time as a result of differences in climatic regimes. Changes in spatial distribution of these variables have yet to be investigated at spatial resolutions suitable for ecological-restoration planning. In the past 50 years, especially under the background of climate change, it is largely uncertain if aridity patterns have changed in N China.

We analysed the changes in precipitation, air temperature, aridity, and vegetation dynamics in the deserts of $\mathrm{N}$ China. Changes in vegetation cover and aridity (gaged by the aridity index, AI) are tracked with the assistance of chronological series of surfaces based on the mapping of normalized difference vegetation index (NDVI) and AI. The analysis is based on 30 meteorological and NDVI data from 1961-2013 and 1982-2013, respectively. The objectives of the study were to (1) understand the role of climate change in effecting vegetation cover in desert regions of N China, and (2) discuss their possible impact on ecological restoration. Our specific aims were to (1) quantify trends in spatiotemporal variation in precipitation and 
Biogeosciences Discuss., doi:10.5194/bg-2016-376, 2016

Manuscript under review for journal Biogeosciences

Published: 16 September 2016

(c) Author(s) 2016. CC-BY 3.0 License.

air temperature and reveal pattern changes in aridity, and (2) track spatiotemporal changes in vegetation dynamics with respect to plant growth and plant-cover expansion and contraction in corroborating our assessments of climatic change.

\section{Materials and methods}

\subsection{Study regions}

5 Desert regions of $\mathrm{N}$ China $\left(75^{\circ}-125^{\circ} \mathrm{E}\right.$ longitude, $35^{\circ}-50^{\circ} \mathrm{N}$ latitude) cover approximately $172.1 \times 10^{4} \mathrm{~km}^{2}$, accounting for about $\mathbf{1 7 . 9 \%}$ of the total land area of China (State Forestry Administration, P.R. China, 2015a). The land area forms a discontinuous arc-shaped desert belt from the western Tarim Basin to western Songnen Plain. It traverses the NW-, N-, and NE-regions of China with a length of $4,500 \mathrm{~km}$ from east to west and a width of $600 \mathrm{~km}$ from south to north, including most of Xinjiang, Inner Mongolia, Ningxia, N Gansu, Hebei, Heilongjiang, Jilin, Liaoning, and a part of Qinghai and Shaanxi

10 provinces (Zhu and Liu, 1981; Li et al., 2013; Li et al., 2014). These areas are characterized by different climate types, from hyperarid $(\mathrm{AI}<0.05)$, arid $(0.05 \leq \mathrm{AI}<0.2)$, semiarid $(0.2 \leq \mathrm{AI}<0.5)$, to dry subhumid climate types $(0.5 \leq \mathrm{AI}<0.65 ; \mathrm{Hulme}$, 1996; Middleton and Thonas, 1997). The deserts span two vegetation zones; steppes in the east and temperate deserts in the west of the Helan Mountain Range ( $106^{\circ}$ E longitude). Harsh natural conditions (e.g., drought, wind erosion, sparse vegetation, and infertile soils), combined with anthropogenic undertakings (e.g., overgrazing, excess land reclamation, irrational exploitation of water resources, and so on), has resulted in serious land degradation and desertification in many parts of these regions. To improve ecological conditions, the Chinese government's “Grain for Green” program (1999-present) was responsible in re-planting vast areas of $\mathrm{N}$ China. By the end of $2014,15.93 \times 10^{4} \mathrm{~km}^{2}$ of $\mathrm{N}$ China had been converted into forests and grassland (State Forestry Administration, P.R. China, 2015b).

\subsection{Data source and processing}

20 By means of desert (Zhu et al., 1980) and sand-covered desert classification maps of China, at a 1:100,000 scale (http://westdc.westgis.ac.cn), we were able to delineate boundaries of twelve deserts, namely the Hulun Buir, Horqin, Otindag, Hobq, Mu Us, Ulanbuh, Tengger, Badain Jaran, Qaidam, Kumtag, Gurbantunggut, and Taklimakan Deserts (Fig. 1). Timeseries of mean, minimum, and maximum air temperature, air pressure, wind speed, relative humidity, sunshine hours, and precipitation from January 01, 1961 to December 31, 2013, were collected from 113 meteorological stations (Fig. 1) through China's Meteorological Data Sharing Service System (http://www.escience.gov.cn/metdata/page/index.html). Data with respect to vegetation was based on 15-day resolution timeseries of Global Inventory Modeling and Mapping Studies (GIMMS) NDVI, with an original spatial resolution of $8 \mathrm{~km}$, http://ecocast.arc.nasa.gov/data/pub/gimms/3g.v0/. Spatial interpolation of meteorological data is based in part on an 8-km re-sampling of an existing 1-km resolution digital elevation model (DEM) developed by the Heihe Project Data Management Centre (http://heihedata.org/).

Incomplete timeseries were gap filled with linear regression with complete timeseries from adjacent meteorological stations serving as independent variable. To assess the spatial variation in annual trends in precipitation, air temperature, and AI, spatial interpolation of meteorological data was performed at a spatial resolution of $8 \mathrm{~km}$ using the thin-plate smoothing spline method 
Biogeosciences Discuss., doi:10.5194/bg-2016-376, 2016

Manuscript under review for journal Biogeosciences

Published: 16 September 2016

(c) Author(s) 2016. CC-BY 3.0 License.

of Hutchinson (2004; http://cres.anu.edu.au/). We generated annual composites of NDVI from the 15-day images with the maximum value composite method.

\subsection{Aridity Index}

Aridity index (AI) is used to analyse the spatiotemporal variation of dryness in desert regions of $\mathrm{N}$ China. It was calculated

5 from:

$\mathrm{AI}=\frac{P}{P E T}$,

where $P$ is the annual precipitation $(\mathrm{mm})$ and $P E T$ is the annual potential evapotranspiration $(\mathrm{mm})$ based on the summation of daily reference evapotranspiration (i.e., $P E T_{o}$, in $\mathrm{mm} \mathrm{d}^{-1}$ ) calculated with the Penman-Monteith equation (Allen et al., 1998), i.e.,

$10 P E T_{o}=\frac{0.408 \Delta\left(R_{n}-G\right)+\gamma \frac{900}{T+273} u_{2}\left(e_{S}-e_{a}\right)}{\Delta+\gamma\left(1+0.34 u_{2}\right)}$,

where $R n$ and $G$ are the net radiation and soil heat flux (in $\left.\mathrm{MJ} \mathrm{m}{ }^{-2} \mathrm{~d}^{-1}\right), \gamma$ is the psychometric constant $\left(\mathrm{kPa}^{\circ} \mathrm{C}^{-1}\right), e_{s}$ is the saturation vapor pressure $(\mathrm{kPa}), e_{a}$ is the actual vapor pressure $(\mathrm{kPa}), \Delta$ is the slope of the saturation vapor pressure-vs.-air temperature curve $\left(\mathrm{kPa}{ }^{\circ} \mathrm{C}^{-1}\right), T$ is the average daily mean air temperature $\left({ }^{\circ} \mathrm{C}\right)$, and $U_{2}$ is the mean daily wind speed at a $2-\mathrm{m}$ height $\left(\mathrm{m} \mathrm{s}^{-1}\right)$. Computation of variables in Eq. (2) follow the approaches used by the Food and Agriculture Organization of

15 the United Nations (FAO). The main radiation component of Eq. (2) is calculated from:

$R_{n}=R_{n s}-R_{n l}$,

$R_{n s}=(1-\alpha) R_{s}$,

$R_{s}=\left(a+b \frac{n}{N}\right) R_{a}$

$R_{n l}=\sigma\left(\frac{T_{x k}^{4}+T_{n k}^{4}}{2}\right)\left(0.34-0.14 \sqrt{e_{a}}\right)\left(1.35 \frac{R_{S}}{R_{S 0}}-0.35\right)$,

20 where $R_{a}$ is the extraterrestrial radiation, $R_{s}$ is the incident solar radiation, $R_{s o}$ is the clear-sky solar radiation, $R_{n s}$ and $R_{n l}$ are the net shortwave and longwave radiation (all, in $\left.\mathrm{MJ} \mathrm{m}^{-2} \mathrm{~d}^{-1}\right), \alpha$ is the albedo ( $\alpha=0.23$ for desert environments, Warner, 2004), $n$ and $N$ are the actual and maximum possible sunshine duration (h), $\sigma$ is the Stefan-Boltzmann constant $\left(4.903 \times 10^{-9} \mathrm{MJ} \mathrm{K}^{-4}\right.$ $\left.\mathrm{m}^{-2} \mathrm{~d}^{-1}\right), T_{x k}$ and $T_{n k}$ are the maximum and minimum absolute temperature during any 24-h period (K), and $a$ and $b$ are empirical coefficients (i.e., $a=0.161$ and $b=0.614$, after Wang et al., 2014). Variables $R_{a}, R_{s o}$, and $N$ were calculated from 25 solar constant, latitude, elevation, and the number of days in the year following procedures outlined in the FAO56 report. 
Biogeosciences Discuss., doi:10.5194/bg-2016-376, 2016

Manuscript under review for journal Biogeosciences

Published: 16 September 2016

(c) Author(s) 2016. CC-BY 3.0 License.

\subsection{Mann-Kendall test}

To detect changes in precipitation, air temperature, and AI in the twelve deserts, the Mann Kendall (M-K) non-parametric test was used. For a timeseries of " $n$ " observations (i.e., $\mathrm{x}_{1}, \mathrm{x}_{2}, \ldots, \mathrm{x}_{n}$ ), the M-K test is based on the S-statistic, which is computed from

$5 \mathrm{~S}=\sum_{i=1}^{\mathrm{n}-1} \sum_{j=i+1}^{n} \operatorname{sgn}\left(x_{j}-x_{i}\right)$,

where

$\operatorname{sgn}\left(x_{j}-x_{i}\right)=\left\{\begin{aligned} 1 & x_{j}>x_{i} \\ 0 & x_{j}=x_{i} \\ -1 & x_{j}<x_{i}\end{aligned}\right.$

When the sample size $(\mathrm{n}) \geq 8$, the variance of the S-statistics is calculated from

$\operatorname{Var}(S)=\frac{n(n-1)(2 n+5)-\sum_{k=1}^{m} t_{k}\left(t_{k}-1\right)\left(2 t_{k}+5\right)}{18}$

10 (Mann, 1945; Kendall, 1975), where "m" is the number of tied groups, $t_{k}$ denotes the number of ties for $x_{j}>x_{i}$. A tied group is a set of sample data having the same value. The standardized M-K test statistic is obtained from

$Z=\left\{\begin{array}{cl}\frac{S-1}{\sqrt{\operatorname{Var}(S)}} & S>0 \\ 0 & S=0 . \\ \frac{S+1}{\sqrt{\operatorname{Var}(S)}} & S<0\end{array}\right.$

If $|\mathrm{Z}|>\mathrm{Z}_{1-p / 2}$, a significant trend exists in the timeseries. If $|\mathrm{Z}|>1.64$, it indicates a statistically significant trend at a significance level of $p=0.1$; whereas $|Z|>1.96$ and $>2.576$ denote statistically significant trends at $p=0.05$ and 0.01 ,

15 respectively. A positive value of $Z$ indicates an 'upward trend', whereas a negative value indicates a 'downward trend'; zero corresponds with 'no statistically detectable trend'. To estimate the actual rate-of-change (i.e., trend) in the data we employ localized linear regression at individual image pixels. By definition, the slope of the regression line is equivalent to the rateof-change in the timeseries data.

\subsection{Convergent cross mapping}

20 Convergent cross mapping is a model-free method that detects cause-and-effect relationships and direction of cause-and-effect in dynamic systems (Sugihara et al., 2012). As a general rule, timeseries are considered causally related if both timeseries originate from the same system. Convergent cross mapping tests for cause-and-effect by determining the extent historical records in one timeseries can reliably determine the state in a second timeseries. The method provides consistent description of cause-and-effect even in the presence of system feedback and confoundedness (Sugihara et al., 2012). Moreover, convergent cross mapping involves convergence, a distinct feature of the method that distinguishes cause-and-effect from conventional 
Biogeosciences Discuss., doi:10.5194/bg-2016-376, 2016

Manuscript under review for journal Biogeosciences

Published: 16 September 2016

(c) Author(s) 2016. CC-BY 3.0 License.

correlation. Ordinarily, non-causal associations are illustrated as horizontal, non-convergent curves of predictive skill generated from calculations of Pearson's correlation coefficient between predictions and actual observations as timeseries record lengths are extended. Cause-and-effect relationship between variables is inferred when convergence is present and Pearson's correlation coefficient at the point of convergence is $>0.0$.

\section{3. Results}

\subsection{Precipitation}

Figure 2 provides the annual precipitation from 1961-2013 for the twelve deserts. The results indicate annual fluctuations in precipitation, with an obvious drop in precipitation from east to west. According to the M-K test, precipitation increased for seven of the twelve deserts, namely for the Ulanbuh, Tengger, Badain Jaran, Qaidam, Kumtag, Gurbantunggut, and

10 Taklimakan Deserts. A statistically strong increasing trend was observed for the Gurbantunggut $(p<0.01)$ and the Taklimakan Deserts $(p<0.1)$. In contrast, five of the deserts (i.e., Hulun Buir, Horqin, Otindag, Hobq, and Mu Us) demonstrated declining trends in precipitation. However, these trends were not statistically significant (Table 1).

In addition, slopes in precipitation exhibited increasing trends in seven of the deserts, in order from lowest to highest, Kumtag, Tengger, Badain Jaran, Qaidam, Ulanbuh, Taklimakan, and Gurbantunggut Deserts, with a rate-of-change of 0.05-

$151.21 \mathrm{~mm} \mathrm{yr}^{-1}$, and decreasing trends in Hobq, Otindag, Mu Us, Hulun Buir, and Horqin Deserts, with a rate-of-change of $0.17,-0.33,-0.35,-0.54$, and $-0.88 \mathrm{~mm} \mathrm{yr}^{-1}$, respectively (Table 1 ).

Results of linear regression on annual precipitation at the pixel-level are summarized in Fig. 3. The results show that during the observation period (1961-2013), an increasing trend in precipitation occurred within about $70 \%$ of $\mathrm{N}$ China, mainly in the western half of the greater desert region (Fig. 1). The trends are statistically significant and strongest in the northern-half of

20 the western desert region $(p<0.05)$; whereas, a decreasing, though not statistically significant, trend (i.e., $p>0.05)$ was observed to have occurred in the eastern part of the study area, affecting about $30 \%$ of the greater desert region.

\subsection{Mean air temperature}

Timeseries of annual mean air temperature (1961-2013) for the twelve deserts are shown in Fig. 2. The M-K tests show that all twelve deserts exhibited a statistically significant upward trend in air temperature $(p<0.01$; Table 1$)$. Similar trends were detected by linear regression (Table 1). Highest rate of air temperature change was observed to have occurred in the Hobq Desert at $0.082^{\circ} \mathrm{C} \mathrm{yr}^{-1}$, amounting to about 6.3 times greater than the lowest rate determined for the Ulanbuh Desert (i.e., $0.013^{\circ} \mathrm{C} \mathrm{yr}^{-1}$ ). Figure 4 shows the changes in annual mean air temperature over the various deserts. Unsurprisingly, $97 \%$ of the greater desert region was associated with a distinct rising trend in annual temperature $(p<0.05)$ with the majority of the area

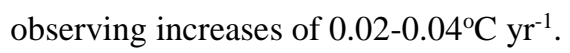


Biogeosciences Discuss., doi:10.5194/bg-2016-376, 2016

Manuscript under review for journal Biogeosciences

Published: 16 September 2016

(c) Author(s) 2016. CC-BY 3.0 License.

\subsection{Aridity}

Timeseries of annual AI show annual fluctuations, with a strong drying trend from east to west (Fig. 2). According to M-K tests, the Ulanbuh, Badain Jaran, Qaidam, Kumtag, Gurbantunggut, and Taklimakan Deserts exhibited wetting trends, which were especially strong for the Gurbantunggut $(p<0.01)$, Taklimakan $(p<0.05)$, and Qaidam Deserts $(p<0.05)$. Drying trends observed for the Hulun Buir, Horqin, Otindag, Hobq, Mu Us, and Tengger Deserts were not statistically significant at $p=0.05$ (Table 1).

Results from linear regression supported our earlier trend analysis with a rate-of-change of 0.0006-0.013 per decade. The highest positive rate-of-change in AI was for the Gurbantunggut Desert (0.0013) and the lowest for the Kumtag Desert (0.00006). A declining (i.e., drying) trend was detected for the Hulun Buir, Horqin, Otindag, Hobq, Mu Us, and Tengger

10 Deserts with a rate-of-change of -0.00014 to -0.008 per decade.

Overall, the results indicated that $\mathrm{AI}$ in more than half of the deserts (63.6\%; Fig. 1) exhibited a wetting trend (i.e., increasing AI); this trend, for the most part, was statistically significant. About $36.4 \%$ of the affected area exhibited a drying trend (decreasing AI), though not statistically significant (Fig. 5). This suggests that most of the desert belt of $\mathrm{N}$ China is experiencing some level of wetting. As shown in Fig. 5, the wetting zones were mainly distributed in the western desert region $(p<0.05)$.

15 The higher rates-of-change appear in the NW of the belt, with a rate-of-change $>0.005$ per decade.

\subsection{Vegetation dynamics}

Spatial distribution of annual mean NDVI from 1982-2013 largely shows a gradual reduction in vegetation vigor and cover from east to west, with the higher values of NDVI occurring in the oases within the western part of the greater desert region (Fig. 6). Areas of annual mean NDVI $<0.1$ were considered non-vegetated areas and were excluded from analysis. Results of

20 linear regression on NDVI are summarized in Fig. 7. Spatial dynamics of annual NDVI indicate that vegetation growth largely improved in the oases in the western half of the desert belt over the 1982-2013 period $(p<0.1)$; however, inconsistent trends of annual NDVI (both increasing and decreasing) are scattered throughout the eastern part of the greater desert region ( $p<$ 0.1 ); only a statistically significant increase occurred in the Mu Us Desert; three deserts, namely the Hulun Buir, Otindag, and Horqin Deserts, had statistically non-significant results.

25 Convergent cross mapping directly related independently-derived estimates of annual vegetation cover (NDVI) to annual changes in aridity (A causes B; $p$ 0.05). The reverse, i.e., B (changes in NDVI) causes A (changes in AI; Fig. 8), failed to support that local changes in NDVI by landuse processes (grazing, land conversion) contributed to an observable change in aridity ( $p=0.37$ and non-convergence of the predictive skill curve of B causes A; Fig. 8), eliminating the possibility of feedback between the two variables at the spatial resolution of the study. 
Biogeosciences Discuss., doi:10.5194/bg-2016-376, 2016

Manuscript under review for journal Biogeosciences

Published: 16 September 2016

(c) Author(s) 2016. CC-BY 3.0 License.

\section{Discussion}

According to global trends, precipitation has generally increased over the Northern Hemisphere at middle to high latitudes, with wet areas becoming wetter and dry areas becoming drier (New et al., 2001; Dore, 2005). Our results suggest an opposite trend, where dry areas have become wetter and wet areas have become drier, although not statistically significant in all cases.

5 Clearly, these findings emphasize the complexity of short- to long-term spatiotemporal patterns in meteorological/climatological processes in desert regions. According to the IPCC (2013), climatic variability combined with human-induced emission of greenhouse gases has resulted in an increase of near-surface air temperatures of $0.72{ }^{\circ} \mathrm{C}$ during the 1951-2012 period, amounting to a $0.01^{\circ} \mathrm{C} \mathrm{yr}^{-1}$ increase. Our study shows that the effect of global climate change has resulted in far greater increases in the deserts of $\mathrm{N}$ China, averaging to about $0.025^{\circ} \mathrm{C} \mathrm{yr}^{-1}$ from $1961-2013$. This increase was about 2.5

10 times greater than the global rate. In terms of aridity, our results are consistent with findings previously reported for NW China and semiarid regions of Inner Mongolia (e.g., Huo et al., 2013; Zhou et al., 2015). Historical trends in NW China are in contrast to the 'dry gets drier and wet gets wetter' association that we currently see globally (Melillo et al., 1993; Herrmann et al., 2005; Whitford, 2002; Lioubimtseva, 2004; Donohue et al., 2009).

Precipitation is an important driving factor for vegetation growth and development in drylands (Cleland et al., 2007; Zhang

15 et al., 2006; Xin et al., 2008; Fig. 8). In general, increased precipitation and aridity index is followed by improvements in vegetation cover (Zhang et al., 2013). In our study, historical trends in NDVI exhibited obvious spatial variations with a decreasing trend from east to west, analogous to the patterns we observe in precipitation (Fig. 6). Elevated air temperatures may cause the melting of high-elevation glaciers (a major source of water in the inland arid areas of NW China; Wang et al., 2008; Sorg et al., 2012; Hua and Wang, 2014; Matin and Bourque, 2015) to accelerate (Zhang et al., 2016), potentially

20 increasing the amount of water available for oasis agriculture and vegetation establishment.

Matin and Bourque (2015) show through their work that vegetation cover dynamics and surface evaporation in the lowland oases of two large endorheic (hydrologically-closed) watersheds of central Gansu (expressed in terms of satellite-based estimates of enhanced vegetation index) was causally related to the production of precipitation in the Qilian Mountains (south of the oases) and precipitation in the mountains was causally related to the seasonal phenology and coverage of oases vegetation, with the former relation providing the stronger feedback control. Convergent cross mapping of within-oasis production of precipitation through localized convective processes is shown to have no causal relation with NDVI in the oases (i.e., $p>0.05$ and convergence is absent). This assessment is consistent with the view that in-mountain production of precipitation through orographic-lifting of evaporated water from the oases and surface and shallow subsurface return flow from the mountains is central to sustaining healthy growing vegetation in the oases (Bourque and Matin, 2012; Matin and Bourque, 2015). Added

30 water resources to the oases in the form of glacial meltwater should help sustain the oases for some time into the future, providing that the vegetation cover in the oases (i.e., transpiration pump) is not radically altered by urbanization and other forms of land conversion (Bourque and Hassan, 2009). For semiarid regions of NE China undergoing drying, rising air 
Biogeosciences Discuss., doi:10.5194/bg-2016-376, 2016

Manuscript under review for journal Biogeosciences

Published: 16 September 2016

(c) Author(s) 2016. CC-BY 3.0 License.

temperatures may accelerate surface evaporation (Hao et al., 2012; Xin et al., 2008) and cause vegetation vigor and cover to decline, potentially promoting desertification.

Although impacts of precipitation and air temperature on ecosystems are important, ecological processes of ecosystems are largely influenced by their integrated effects (aridity vs. vegetation, Fig. 8). Spatiotemporal patterns of aridity determine the

5 spatial structures and evolution of plant communities (Fernandez-Illescas and Rodriguez-Iturbe, 2004; Oguntunde et al., 2006; McVicar et al., 2007; Jiapaer et al., 2015; Fig. 8) and the process of desertification in arid-to-semiarid regions (Wang, et al., 2009). As illustrated in Fig.8, annual changes in NDVI are shown to be controlled to a large measure by annual changes in aridity ( $p<0.05+$ convergence). Clearly, the integrity of the vegetation cover assessed at regional scales (i.e., $8 \mathrm{~km})$ is more greatly influenced by changes in mesoscale-to-synoptic scale circulation patterns (Ye et al., 2013) and delivery of glacial

10 meltwater to the oases in the west. Prominence of small-scale landuse practices on aridity (e.g., von Hardenberg et al., 2001), especially those related to over-exploitation and over-grazing (if present), remain concealed at the current spatial resolution.

The relationship between AI and NDVI at 8-km resolution suggest that patterns of wetting in the western desert region in the past 53 years have led to small improvements in vegetation cover (NDVI, Fig.7) and potentially alleviated planning concerns associated with the sustainable development of existing oases (Zhu et al., 1981). If the trend continues, patterns of

15 wetting in the western desert regions could potentially improve ecological conditions, promote desertification reversal, and reduce reliance on groundwater for crop irrigation. In contrast, continued drying in the eastern deserts would likely encumber agricultural operations, vegetation growth, and ecological restoration in the Hulun Buir, Horqin, Otindag, Hobq, Mu Us, and Tengger Deserts (Fig. 7) in the future.

Given the massive re-vegetation programs of the past (circa 1999 to the present) and planned re-vegetation programs for the 20 next planning cycle, ending in 2050 (Lal, 2001 and 2004; Feng et al., 2016), it is important to recognize that vegetationrestoration projects may contribute to water shortages that may ultimately lead to their failure, especially in semiarid areas undergoing drying. Therefore, under this backdrop, pattern changes in drying/wetting should be taken into account in balancing re-vegetation projects with the domestic needs for water (Liu and Yang, 2012). This would avoid the excessive restoration of marginally to severely impoverished lands with little possibility of generating ecological and socio-economic return. Revegetation-project planning should ideally place a greater emphasis on vegetation- and land-area-specific carrying capacities (habitat suitability) and their future projections as a function of prevailing climatic, soil, hydrologic, and physiographic factors (Bourque et al., 2000; Bourque and Hassan, 2010; Bourque, 2015). A “one-fit-all” dryland-restoration strategy is not only expensive, but ecologically unsound.

\section{Conclusion}

30 We present an analysis of climate change and associated trends in aridity and vegetation cover in the greater desert belt of $\mathrm{N}$ China based on long-term meteorological records, calculation of aridity index (AI), and satellite-based NDVI. We use convergent cross mapping to investigate the cause-and-effect relationship between aridity and NDVI. At the spatial resolution 
Biogeosciences Discuss., doi:10.5194/bg-2016-376, 2016

Manuscript under review for journal Biogeosciences

Published: 16 September 2016

(c) Author(s) 2016. CC-BY 3.0 License.

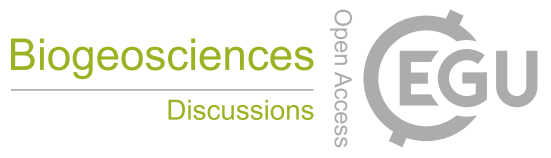

(c) (i)

of this study $(8 \mathrm{~km})$, aridity controls the majority of change in vegetation cover (NDVI), with no statistical support of feedback between these two variables. Trend analysis of precipitation, aridity, and NDVI suggest that climatic conditions in the western desert region in the past 53 years has undergone a level of wetting, leading to small improvements in vegetation cover (NDVI). In contrast, semiarid areas of the eastern desert region have experienced declining ecological conditions over the same time 5 period.

Our results are critical for adaptation planning and desertification management which can provide guidance to the ecological restoration of deserts in $\mathrm{N}$ China. However, promoting sustainable management of re-vegetation projects during the next cycle of restoration planning remains a major challenge. We recommend that more information, such as tolerance of vegetation cover in an environment of increasing demand for water by residential, agricultural, and industrial sectors, be obtained to

10 ensure socio-economic and ecological sustainability of dryland systems. Although, vegetation cover is explicitly not shown to affect aridity by feedback mechanisms at the current resolution, we suggest that further work be done to uncover these relationships as over-exploitation of the land vegetation may lead to further decline, even in instances where precipitation may be trending slightly upwards.

\section{Data availability}

15 Timeseries of mean, minimum, and maximum air temperature, air pressure, wind speed, relative humidity, sunshine hours, and precipitation from January 01, 1961 to December 31, 2013, were obtained from China's Meteorological Data Sharing Service System (http://www.escience.gov.cn/metdata/page/index.html); Global Inventory Modeling and Mapping Studies (GIMMS) NDVI were accessed from http://ecocast.arc.nasa.gov/data/pub/gimms/3g.v0/; while the digital elevation model was obtained from the Heihe Project Data Management Center (http://heihedata.org/).

\section{Author contributions}

YQZ and YYS designed the study of the paper; YYS, YQZ, XQW, and CPAB contributed to the ideas, interpretation of the data, and manuscript writing; CPAB employed CCM in a cause-and-effect analysis of precipitation, AI, and NDVI; YYS contributed to data processing and analysis; all authors contributed to the discussion and commented on the manuscript throughout its development.

\section{Conflicts of Interest}

The authors declare no conflict of interest. 
Biogeosciences Discuss., doi:10.5194/bg-2016-376, 2016

Manuscript under review for journal Biogeosciences

Published: 16 September 2016

(c) Author(s) 2016. CC-BY 3.0 License.

\section{Acknowledgments}

The authors gratefully acknowledge the financial support provided by National Key Basic Research Program of China (No. 2013CB429901) and National Key Research and Development Program of China (No. 2016YFC0500905).

\section{References}

5 Abaya, S. W., Mandere, N. M., and Winqvist, N.: Health officials' perceptions of and preparedness for the impacts of climate variability on human health in the Somali Region of Ethiopia, Mitigation and Adaptation Strategies for Global Change, 16, 585-596, 2011.

Allen, R. G., Pereira, L. S., Raes, D., and Smith, M.: Crop evapotranspiration-Guidelines for computing crop water requirements-FAO Irrigation and drainage paper 56, FAO, Rome, 300, D05109, 1998.

10 Bourque, C.P.-A.: Modelled potential tree species distribution for current and projected future climates for New Brunswick, Canada. Unpubl. Rept. to the New Brunswick Department of Environment and Local Government, Climate Change Secretariat, 40 pp., 2015.

Bourque, C.P.-A., and Hassan, Q.K.: Vegetation control in the long-term self-stabilization of the Liangzhou Oasis of the upper Shiyang River watershed of west-central Gansu, Northwest China. Earth Interactions, 13(13): 1-22, 2009.

15 Bourque, C.P.-A., and Hassan, Q.K.: Modelled potential species distribution for current and projected future climates for Prince Edward Island, Canada. Unpubl. Rept., to Prince Edward Island Department of Environment, Energy, and Forestry, 48 pp., 2010.

Bourque, C.P.-A., and Matin, M.A.: Seasonal snow cover in the Qilian Mountains of Northwest China: Its dependence on oasis seasonal evolution and lowland production of water vapour. J. Hydrol., 454-455, 141-151, 2012.

20 Bourque, C.P.-A., Meng, F.-R., Gullison, J.J., and Bridgland, J.: Biophysical and potential vegetation growth surfaces for a small watershed in Northern Cape Breton Island, Nova Scotia, Canada. Can. J. For. Res., 30, 1179-1195, 2000.

Chen, Z., Yu, G. R., Ge, J. P., Sun, X. M., Hirano, T., Saigusa, N., Wang, Q. F., Zhu, X. J., Zhang, Y. P., Zhang, J. H., Yan, J. H., Wang, H. M., Zhao, L., Wang, Y. F., Shi, P. L., and Zhao, F. H.: Temperature and precipitation control of the spatial variation of terrestrial ecosystem carbon exchange in the Asian region, Agr. Forest Meteorol., 182-183, 266-276, 2013.

Clark, A. T., Ye, H., Isbell, F., Deyle, E. R., Cowles, J., Tilman, G. D., and Sugihara, G.: Spatial convergent cross mapping to detect causal relationships from short time series, Ecol., 96, 1174-1181, 2015.

Cleland, E. E., Chuine, I., Menzel, A., Mooney, H. A., and Schwartz, M. D.: Shifting plant phenology in response to global change, Trends Ecol. Evol., 22, 357-365, 2007.

30 Deng, H. J., Chen, Y. N., Wang, H. J, and Zhang, S. H.: Climate change with elevation and its potential impact on water resources in the Tianshan Mountains, Central Asia, Global Planet. Change, 135, 28-37, 2015. 
Biogeosciences Discuss., doi:10.5194/bg-2016-376, 2016

Manuscript under review for journal Biogeosciences

Published: 16 September 2016

(c) Author(s) 2016. CC-BY 3.0 License.

Donohue, R. J., McVICAR, T. I. M., and Roderick, M. L.: Climate-related trends in Australian vegetation cover as inferred from satellite observations, 1981-2006, Global Change Bio., 15, 1025-1039, 2009.

Dore, M. H.: Climate change and changes in global precipitation patterns: what do we know?, Environ. Int., 31, 1167-1181, 2005 .

5 Dumenu, W. K. and Obeng, E. A.: Climate change and rural communities in Ghana: Social vulnerability, impacts, adaptations and policy implications, Environ. Sci. Policy, 55, 208-217, 2016.

Feng, X. M., Fu, B. J., Piao, S. L., Wang, S., Ciais, P., Zeng, Z. Z., Lü, Y. H., Zeng, Y., Li, Y., Jiang, X. H., and Wu, B. F.: Revegetation in China's Loess Plateau is approaching sustainable water resource limits, Nature Climate Change, available at: http://www.nature.com/nclimate/journal/vaop/ncurrent/full/nclimate3092.html, last access: 1 July 2016, doi:10.1038/nclimate3092, 2016.

Fernandez-Illescas, C. P. and Rodriguez-Iturbe, I.: The impact of interannual rainfall variability on the spatial and temporal patterns of vegetation in a water-limited ecosystem, Adv. Water Resour., 27, 83-95, 2004.

Fullen, M. A. and Mitchell, D. J.: Desertification and reclamation in north-central China, Ambio, 23, $131-135,1994$.

Gan, T. Y.: Reducing vulnerability of water resources of Canadian prairies to potential droughts and possible climatic warming, Water Resour. Manag., 14, 111-135, 2000.

Hao, F. H., Zhang, X., Ouyang, W., Skidmore, A. K., and Toxopeus, A. G.: Vegetation NDVI linked to temperature and precipitation in the upper catchments of Yellow River, Environ. Model. Assess., 17, 389-398, 2012.

Herrmann, S. M., Anyamba, A., and Tucker, C. J.: Recent trends in vegetation dynamics in the African Sahel and their relationship to climate, Global Environmental Change, 15, 394-404, 2005.

20 Hua, T. and Wang, X. M.: Research progresses on the interaction between desertification and climate change in arid and semiarid East Asia, Progress in Geography, 33, 841-852, 2014.

Hulme, M.: Recent climatic change in the world's drylands, Geophys. Res. Lett., 23: 61-64, 1996.

Huo, Z. L., Dai, X. Q., Feng, S. Y., Kang, S. Z., and Huang, G. H.: Effect of climate change on reference evapotranspiration and aridity index in arid region of China, J. Hydrol., 492, 24-34, 2013.

25 Hutchinson, M. F.: ANUSPLIN Version 4.3 User Guide, the Australia National University, Center for Resource and Environment Studies, Canberra, Australia, available at: http://cres.anu.edu.au/outputs/anusplin.Php, 2004.

IPCC: climate change 2013: The physical science basis, Contribution of Working Group I to the Fifth Assessment Report of the Intergovernmental Panel on Climate Change, Cambridge University Press, Cambridge, United Kingdom and New York, NY, USA, 2013.

30 Jentsch, A. and Beierkuhnlein, C.: Research frontiers in climate change: effects of extreme meteorological events on ecosystems, C. R. Geosci., 340, 621-628, 2008.

Jiapaer, G., Liang, S. L., Yi, Q. X., and Liu, J. P.: Vegetation dynamics and responses to recent climate change in Xinjiang using leaf area index as an indicator, Ecol. Indic., 58, 64-76, 2015.

Kendall, M. G.: Rank Correlation Methods, Griffin, London, UK, 1-200 pp., 1975. 
Biogeosciences Discuss., doi:10.5194/bg-2016-376, 2016

Manuscript under review for journal Biogeosciences

Published: 16 September 2016

(c) Author(s) 2016. CC-BY 3.0 License.

Lal, R.: Potential of desertification control to sequester carbon and mitigate the greenhouse effect, Climatic change, 51, 35-72, 2001.

Lal, R.: Carbon sequestration in dryland ecosystems, Environ. Manage., 33, 528-544, 2004.

Li, B. F., Chen, Y. N., Shi, X., Chen, Z. S., and Li, W. H.: Temperature and precipitation changes in different environments in the arid region of northwest China, Theor. Appl. Climatol., 112, 589-596, 2013.

Li, B. F., Chen, Y. N., Chen, Z. S., Xiong, H. G., and Lian, L. S.: Why does precipitation in northwest China show a significant increasing trend from 1960 to 2010?, Atmos. Res., 167, 275-284, 2016.

Li, X. R., Zhang, Z. S., Huang, L., and Wang, X. P.: Review of the eco-hydrological processes and feedback mechanisms controlling sand-binding vegetation systems in sandy desert regions of China, Chinese Sci. Bull., 58, 1483-1496, 2013.

10 Li, X. R., Zhang, Z. S., Tan, H. J., Gao, Y. H., Liu, L. C., and Wang, X. P.: Ecological restoration and recovery in the windblown sand hazard areas of northern China: relationship between soil water and carrying capacity for vegetation in the Tengger Desert, Science China-Life Sciences, 57, 539-548, 2014.

Li, Y., Huang, J. P., Ji, M. X., and Ran, J. J.: Dryland expansion in northern China from 1948 to 2008, Adv. Atmos. Sci., 32, $870-876,2015$.

15 Lioubimtseva, E.: Climate change in arid environments: revisiting the past to understand the future, Prog. Phys. Geog., 28, 502-530, 2004.

Liu, J. G. and Diamond, J.: China's environment in a globalizing world, Nature, 435, 1179-1186, 2005.

Liu, J. G. and Yang, W.: Water sustainability for China and beyond, Science, 337, 649-650, 2012.

Ma, Z. G., Li, D., and Hu, Y. W.: The extreme dry/wet events in northern China during recent 100 years, J. Geogr. Sci., 14, 275-281, 2004.

Mann, H. B.: Nonparametric tests against trend, Econometrica, 13, 245-259, 1945.

Matin, M.A., and Bourque, C.P.-A.: Relating seasonal dynamics of enhanced vegetation index to the recycling of water in two endorheic river basins in northwest China. Hydrol. Earth Syst. Sci., 19, 3387-3403, 2015.

McVicar, T. R., Li, L. T., Van Niel, T. G., Zhang, L., Li, R., Yang, Q. K., Zhao, Y. A., Zhang, X. P., Mu, X. M., Wen, Z. M.,

25 Liu, W. Z., Zhao, Y. A., Liu, Z. H., and Gao, P.: Developing a decision support tool for China's re-vegetation program: Simulating regional impacts of afforestation on average annual streamflow in the Loess Plateau, Forest Ecol. Manag., 251, 65-81, 2007.

Melillo, J. M., McGuire, A. D., Kicklighter, D. W., Moore, B., Vorosmarty, C. J., and Schloss, A. L.: Global climate change and terrestrial net primary production, Nature, 363, 234-240, 1993.

30 Middleton, N. and Thomas, D.: World atlas of desertification, 2, Hodder Headline, London, UK, 1997.

Moore, S. K., Trainer, V. L., Mantua, N. J., Parker, M. S., Laws, E. A., Backer, L. C., and Fleming, L. E.: Impacts of climate variability and future climate change on harmful algal blooms and human health, Environ. Health-Glob., 7, S4, doi: 10.1186/1476-069X-7-S2-S4, 2008. 
Biogeosciences Discuss., doi:10.5194/bg-2016-376, 2016

Manuscript under review for journal Biogeosciences

Published: 16 September 2016

(c) Author(s) 2016. CC-BY 3.0 License.

New, M., Todd, M., Hulme, M., and Jones, P.: Precipitation measurements and trends in the twentieth century, Int. J. Climatol., 21, 1889-1922, 2001.

Oguntunde, P. G., Friesen, J., van de Giesen, N., and Savenije, H.H.: Hydroclimatology of Volta River Basin in West Africa: trends and variability from 1901 to 2002, Physics and Chemistry of the Earth, Parts A/B/C, 31, 1180-1188, 2006.

5 Pumo, D., Caracciolo, D., Viola, F., and Noto, L. V.: Climate change effects on the hydrological regime of small non-perennial river basins, Sci. Total Environ., 542, 76-92, 2016.

Raghavan, S. V., Vu, M. T., and Liong, S. Y.: Assessment of future stream flow over the Sesan catchment of the Lower Mekong Basin in Vietnam, Hydrol. Process., 26, 3661-3668, 2012.

Sorg, A., Bolch, T., Stoffel, M., Solomina, O., and Beniston, M.: Climate change impacts on glaciers and runoff in Tien Shan (Central Asia), Nature Climate Change, 2, 725-731, 2012.

State Forestry Administration, P.R. China, Bulletin of the desertification and sandification state of China, China Water Power Press, Beijing, China, 2015a.

State Forestry Administration, P.R. China, Bulletin of observation of ecological effects of conversion of cropland to forest program, China Forestry Publishing House, Beijing, China, 2015 b.

15 Sugihara, G., May, R., Ye, H., Hsieh, C. H., Deyle, E., Fogarty, M., and Munch, S.: Detecting causality in complex ecosystems, Science, 338, 496-500, 2012.

von Hardenberg, J., Meron, E., Shachak, M., and Zarmi, Y.: Diversity of vegetation patterns and desertification, Physical Review Letters, 87(19), 198101-1-4, 2001.

Wang, C. L., Yue T. X., and Fan Z. M.: Solar Radiation Climatology Calculation in China, Journal of Resources and Ecology, $5,132-138,2014$.

Wang, F., Pan, X. B., Wang, D. F., Shen, C. Y., and Lu, Q.: Combating desertification in China: past, present and future, Land Use Policy, 31, 311-313, 2013.

Wang, P. X., Zheng, Y. F., He, J. H., Zhang, Q., and Wang, B. J.: Analysis of climate change from dry to wet phase in NW China with an aridity-wetness homogenized index, IEEE International Geoscience and Remote Sensing Symposium, Fort Worth, Texas, USA, 23-28 July 2007, 1778-1781, 2007.

Wang, X. M., Chen, F. H., Hasi, E., and Li, J. C.: Desertification in China: an assessment, Earth-Science Reviews, 88, 188206, 2008.

Wang, X. M., Yang, Y., Dong, Z. B., and Zhang, C. X.: Responses of dune activity and desertification in China to global warming in the twenty-first century, Global and Planetary Change, 67, 167-185, 2009.

30 Warner, T. T.: Desert meteorology, Cambridge University Press, Cambridge, UK, 595 pp., 2004.

Whitford, W.: Ecology of desert systems, Academic Press, London, UK, 343 pp., 2002.

Wu, X. X., Lu, Y. M., Zhou, S., Chen, L. F., and Xu, B.: Impact of climate change on human infectious diseases: Empirical evidence and human adaptation, Environ. Int., 86, 14-23, 2016. 
Biogeosciences Discuss., doi:10.5194/bg-2016-376, 2016

Manuscript under review for journal Biogeosciences

Published: 16 September 2016

(c) Author(s) 2016. CC-BY 3.0 License.

(c) (i)

Xin, Z. B., Xu, J. X., and Zheng, W.: Spatiotemporal variations of vegetation cover on the Chinese Loess Plateau (1981-2006): Impacts of climate changes and human activities, Sci. China Ser. D, 51, 67-78, 2008.

Xu, L. G., Zhou, H. F., Liang, C., Du, L., and Li, H.: Spatial and temporal variability of annual and seasonal precipitation over the desert region of China during 1951-2005. Hydrol. Process., 24, 2947-2959, 2010.

5 Yang, S. L., Ding, Z. L., Li, Y. Y., Wang, X., Jiang, W. Y., and Huang, X. F.: Warming-induced north westward migration of the East Asian monsoon rain belt from the Last Glacial Maximum to the mid-Holocene, Proceedings of the National Academy of Sciences, 112, 13178-13183, 2015.

Ye, J.S., Li, W.H., Li, L.F., and Zhang, F.: "North drying and south wetting" summer precipitation trend over China and its potential linkage with aerosol loading, Atmos. Res., 125-126, 12-19, 2013.

10 Zhang, B. Q., Wu, P. T., Zhao, X. N., Wang, Y. B., and Gao, X. D.: Changes in vegetation condition in areas with different gradients (1980-2010) on the Loess Plateau, China, Environmental earth sciences, 68, 2427-2438, 2013.

Zhang, C., Lu, D. H., Chen, X., Zhang, Y. M., Maisupova, B., and Tao, Y.: The spatiotemporal patterns of vegetation coverage and biomass of the temperate deserts in Central Asia and their relationships with climate controls, Remote Sens. Environ., 175, 271-281, 2016.

15 Zhang, J. T., Ru, W. M., and Li, B.: Relationships between vegetation and climate on the Loess Plateau in China, Folia Geobot., 41, 151-163, 2006.

Zhou, D. J., Zhao, X., Hu, H. F., Shen, H. H., and Fang, J. Y.: Long-term vegetation changes in the four mega-sandy lands in Inner Mongolia, China, Landscape Ecol., 30, 1613-1626, 2015.

Zhu, Z. D., Wu, Z., and Liu, S.: An outline of Chinese deserts, Science Press, Beijing, China, 107, 1980.

Zhu, Z. D. and Liu, S.: Sandy desertification process and its combating regionalization in northern China, Chinese Forestry Press, Beijing, China, 1981. 
Biogeosciences Discuss., doi:10.5194/bg-2016-376, 2016

Manuscript under review for journal Biogeosciences

Published: 16 September 2016

(c) Author(s) 2016. CC-BY 3.0 License.

\section{Figures}

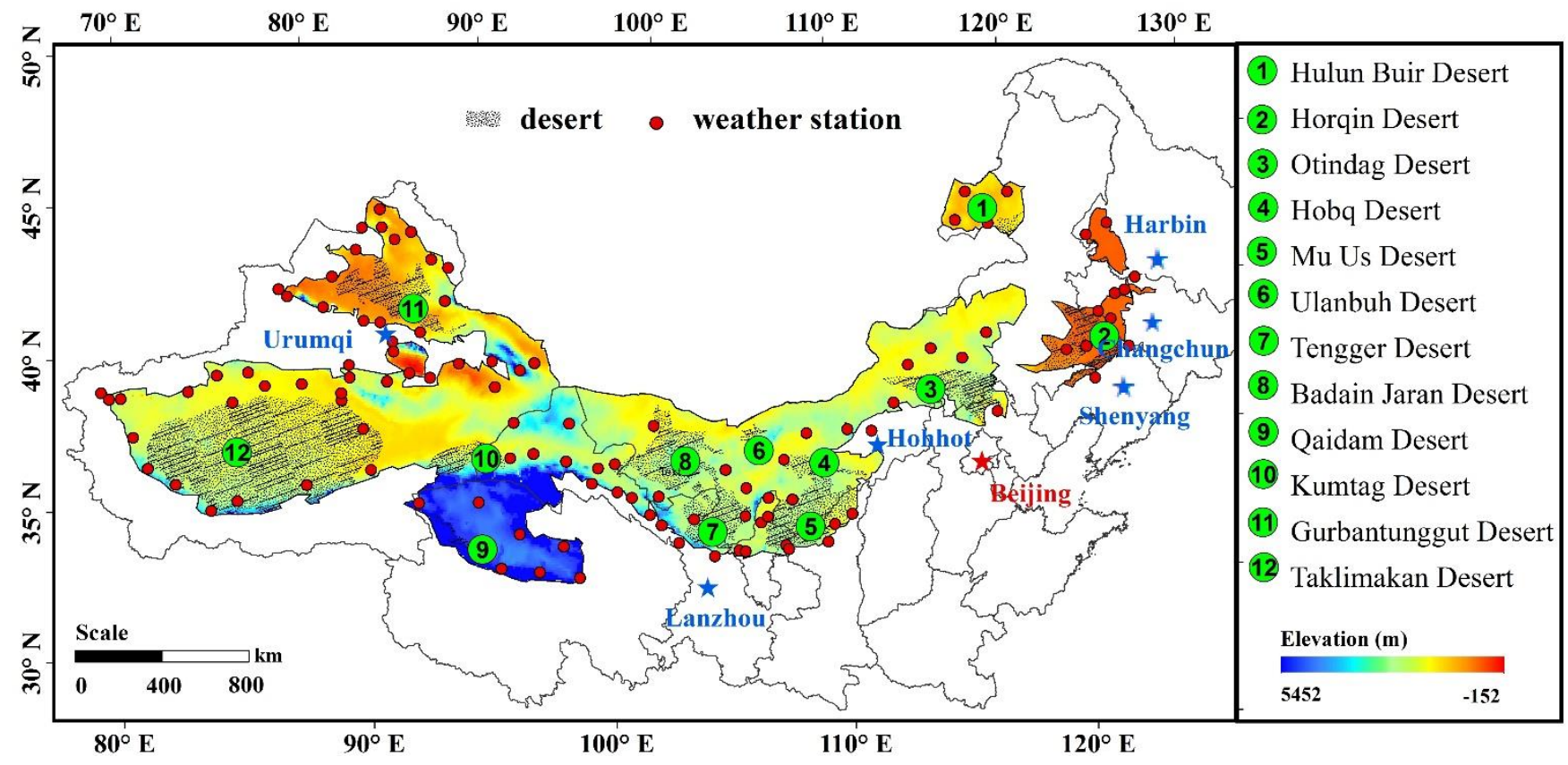

5 Figure 1: Distribution of meteorological stations and deserts across N China. 
Biogeosciences Discuss., doi:10.5194/bg-2016-376, 2016

Manuscript under review for journal Biogeosciences

Published: 16 September 2016

(C) Author(s) 2016. CC-BY 3.0 License.

(c) (i)
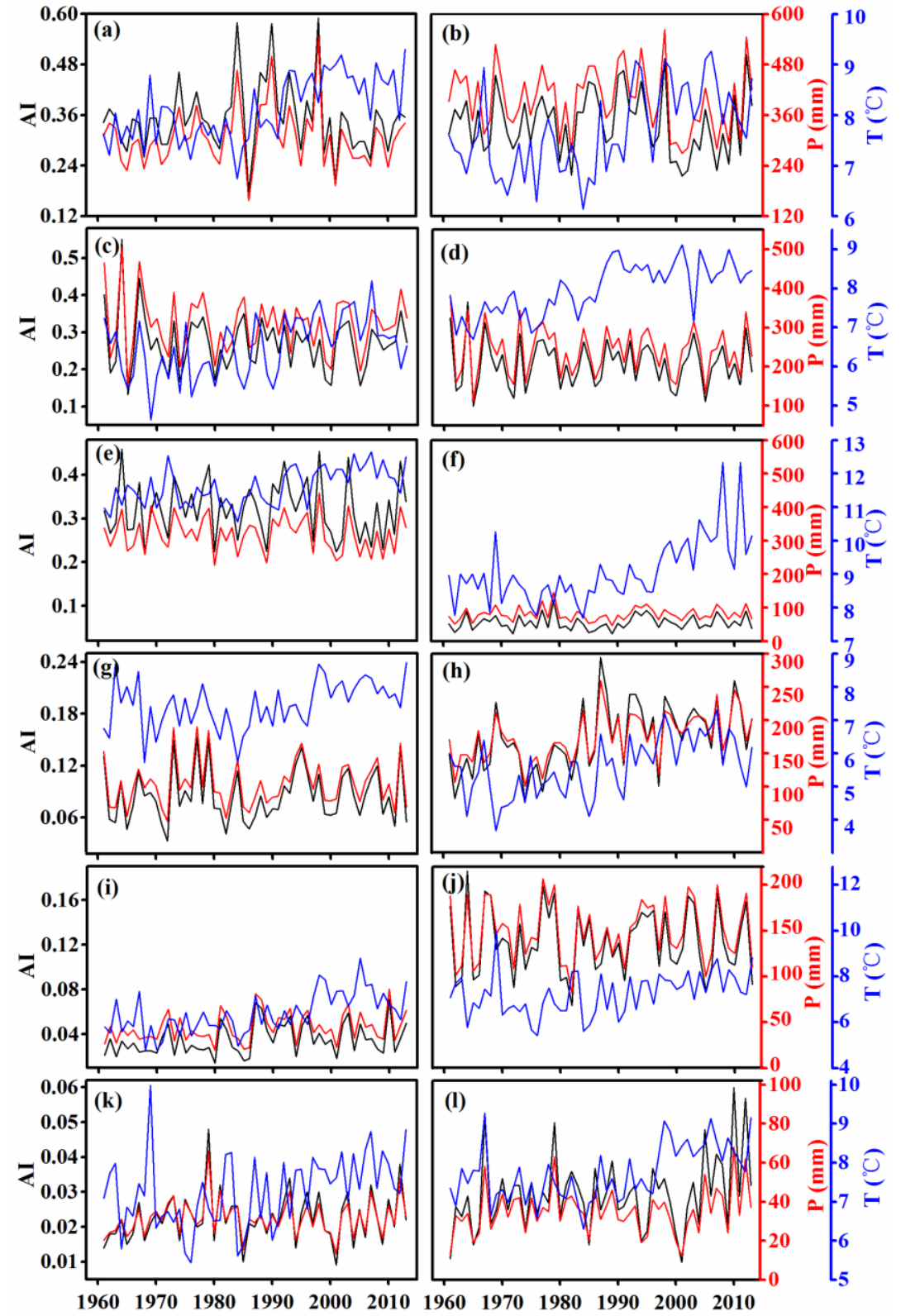

AI

\section{$\mathbf{T}$}

Figure 2: Variation in annual precipitation, mean air temperature, and aridity index from 1961-2013 in the twelve deserts (Fig. 1), (a) Hulun Buir, (b) Horqin, (c) Mu Us, (d) Hobq, (e) Otindag, (f) Badain Jaran, (g) Ulanbuh, (h) Gurbantunggut, (i) Taklimakan, (j) Tengger, (k) Kumtag, and (l) Qaidam Deserts. 
Biogeosciences Discuss., doi:10.5194/bg-2016-376, 2016

Manuscript under review for journal Biogeosciences

Published: 16 September 2016

(c) Author(s) 2016. CC-BY 3.0 License.

(c) (i)

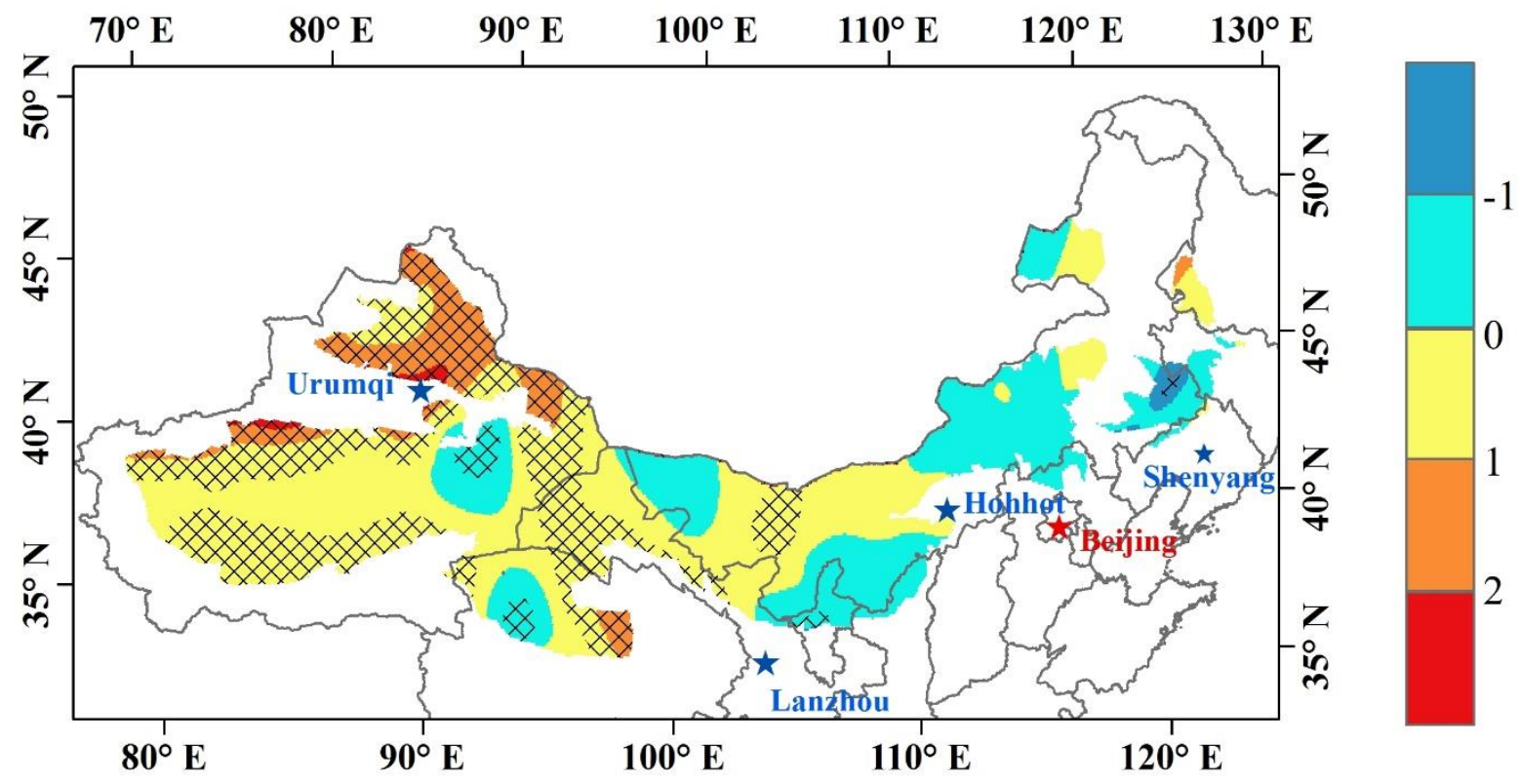

Figure 3: Spatial distribution of temporal trends in annual precipitation $\left(\mathrm{mm} \mathrm{yr}^{-1}\right)$ over the greater desert belt from $1961-2013$ (Fig. 1), based on linear regression. Black crosshatched areas indicate pixels where trends were statistically significant (i.e., $p<0.05)$.

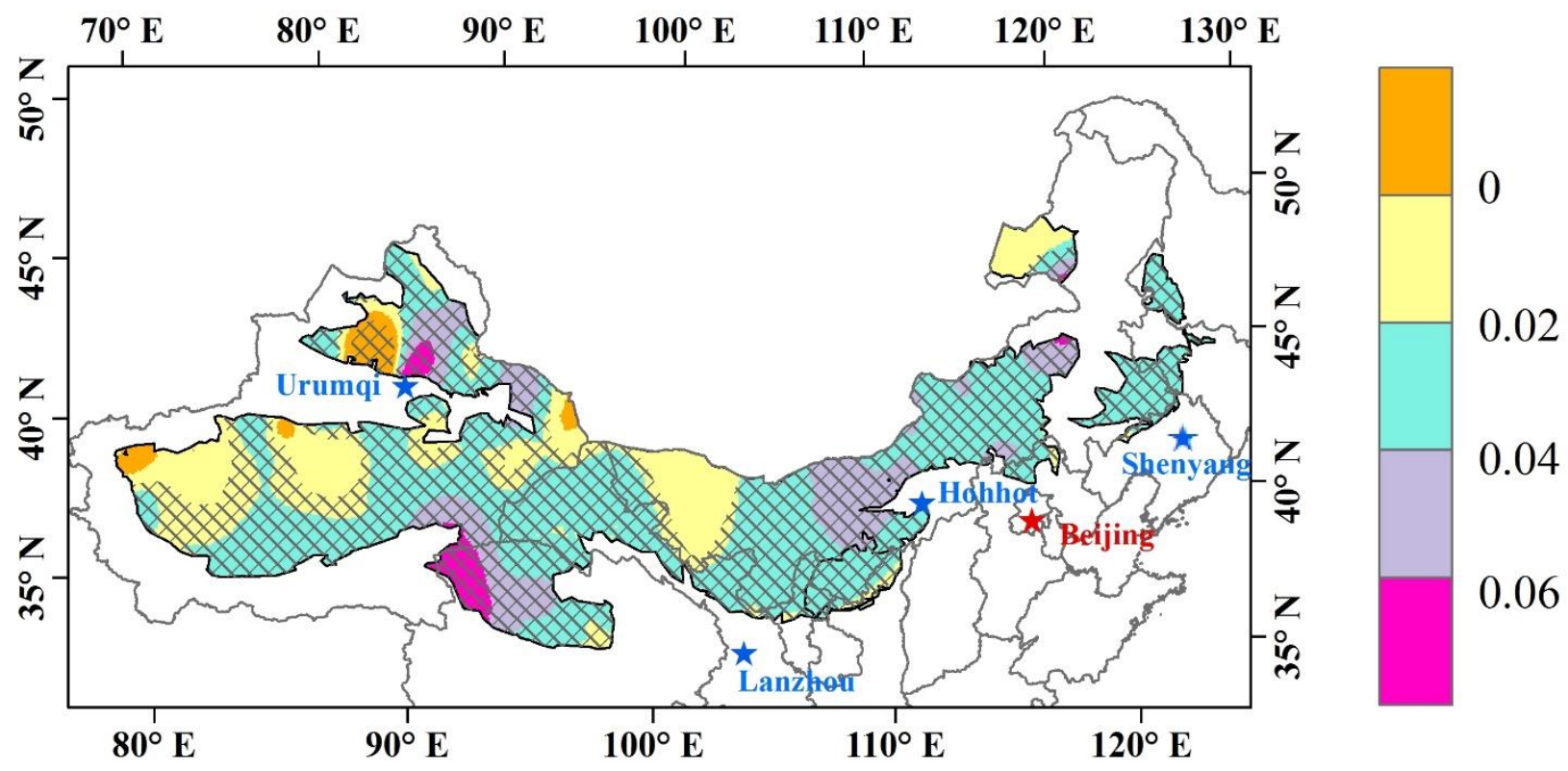

Figure 4: Spatial distribution of temporal trends (1961-2013) in annual mean air temperature $\left({ }^{\circ} \mathrm{C} \mathrm{yr}^{-1}\right)$ over the greater desert belt (Fig. 1), based on linear regression. Black crosshatched areas indicate pixels where trends were statistically significant $(p<0.05)$. 
Biogeosciences Discuss., doi:10.5194/bg-2016-376, 2016

Manuscript under review for journal Biogeosciences

Published: 16 September 2016

(c) Author(s) 2016. CC-BY 3.0 License.

(c) (i)

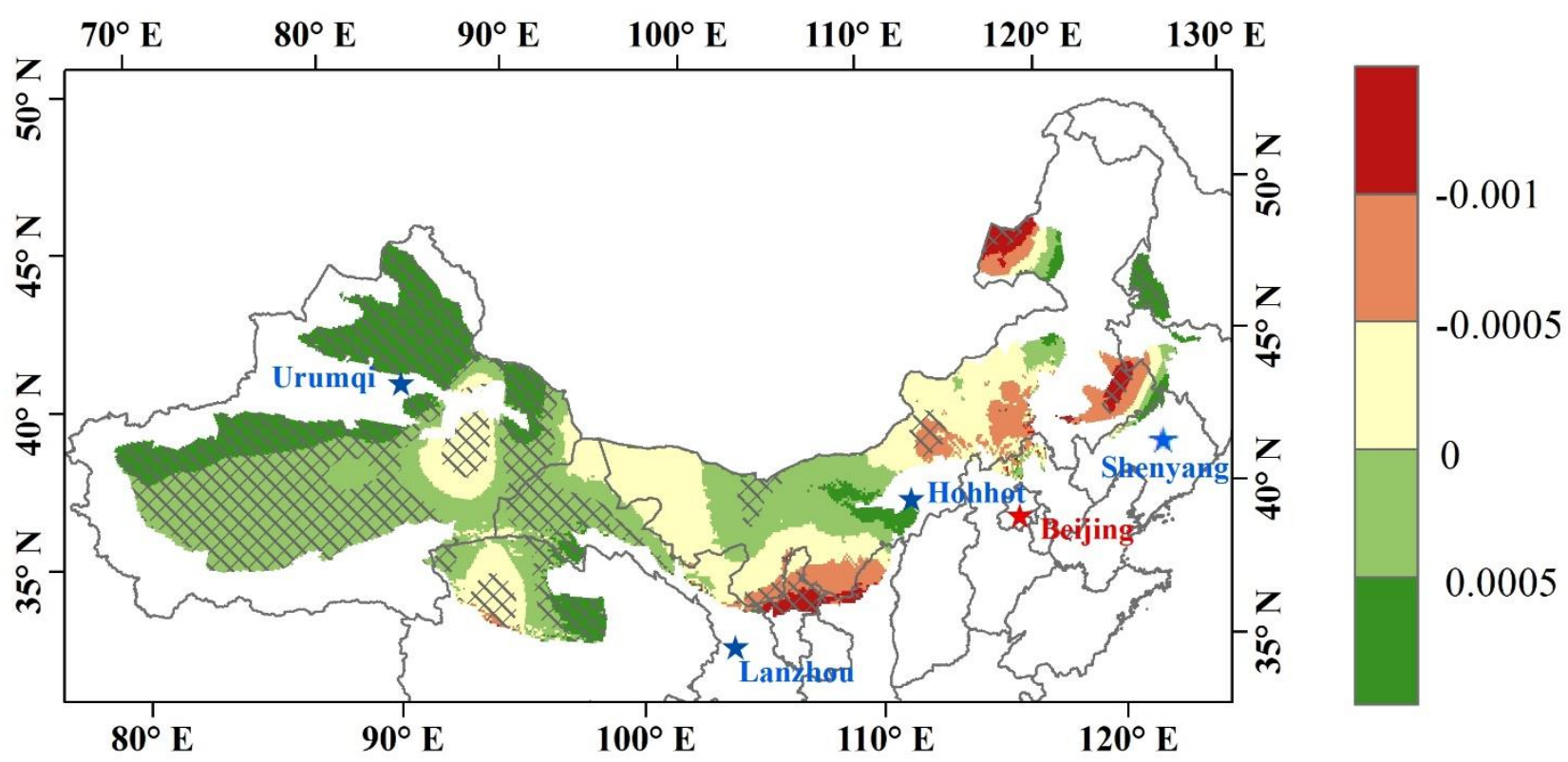

Figure 5: Spatial distribution of temporal trends (1961-2013) in annual aridity index (AI) for the greater desert belt (Fig. 1), based on linear regression. Black crosshatched areas indicate pixels where trends were statistically significant (i.e., $p<0.05$ ). 
Biogeosciences Discuss., doi:10.5194/bg-2016-376, 2016

Manuscript under review for journal Biogeosciences

Published: 16 September 2016

(C) Author(s) 2016. CC-BY 3.0 License.

(c) (1)

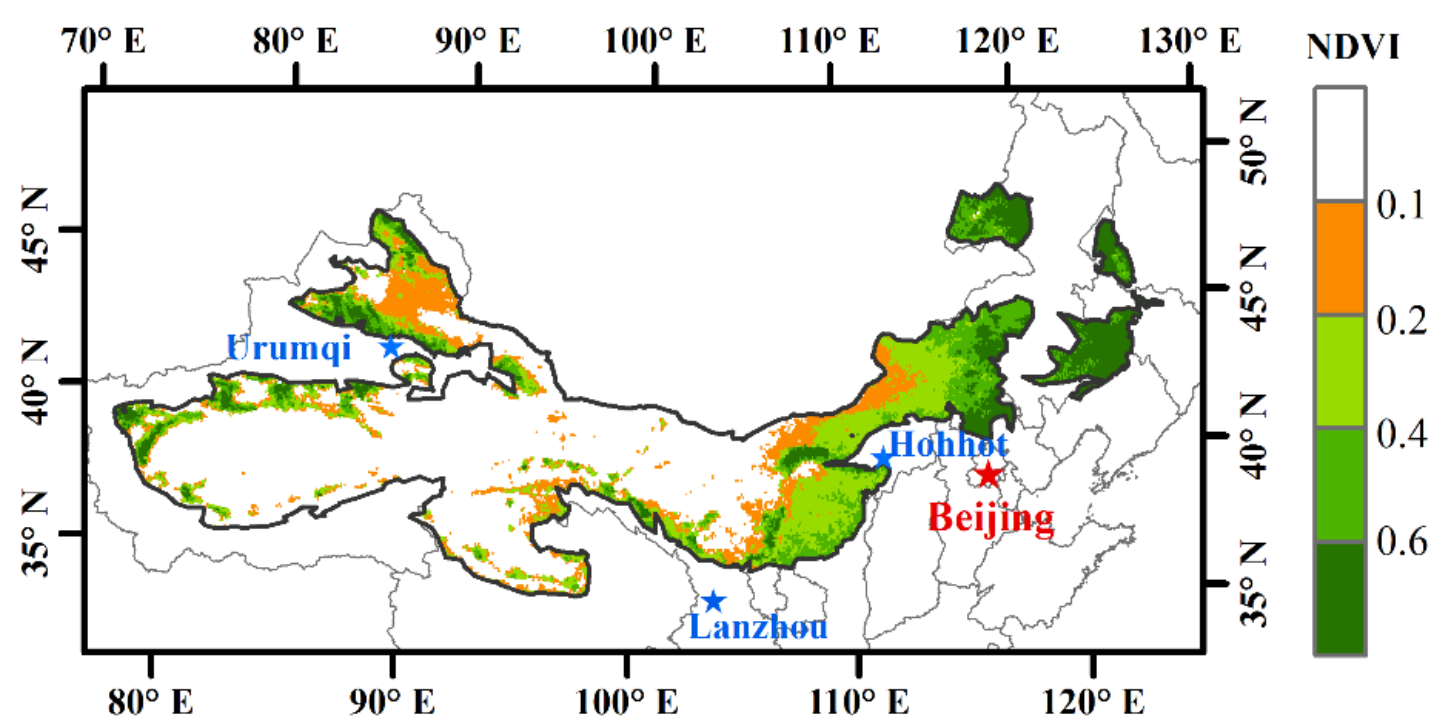

Figure 6: Spatial distribution of annual NDVI (based on data from 1982-2013) for the greater desert belt of N China.

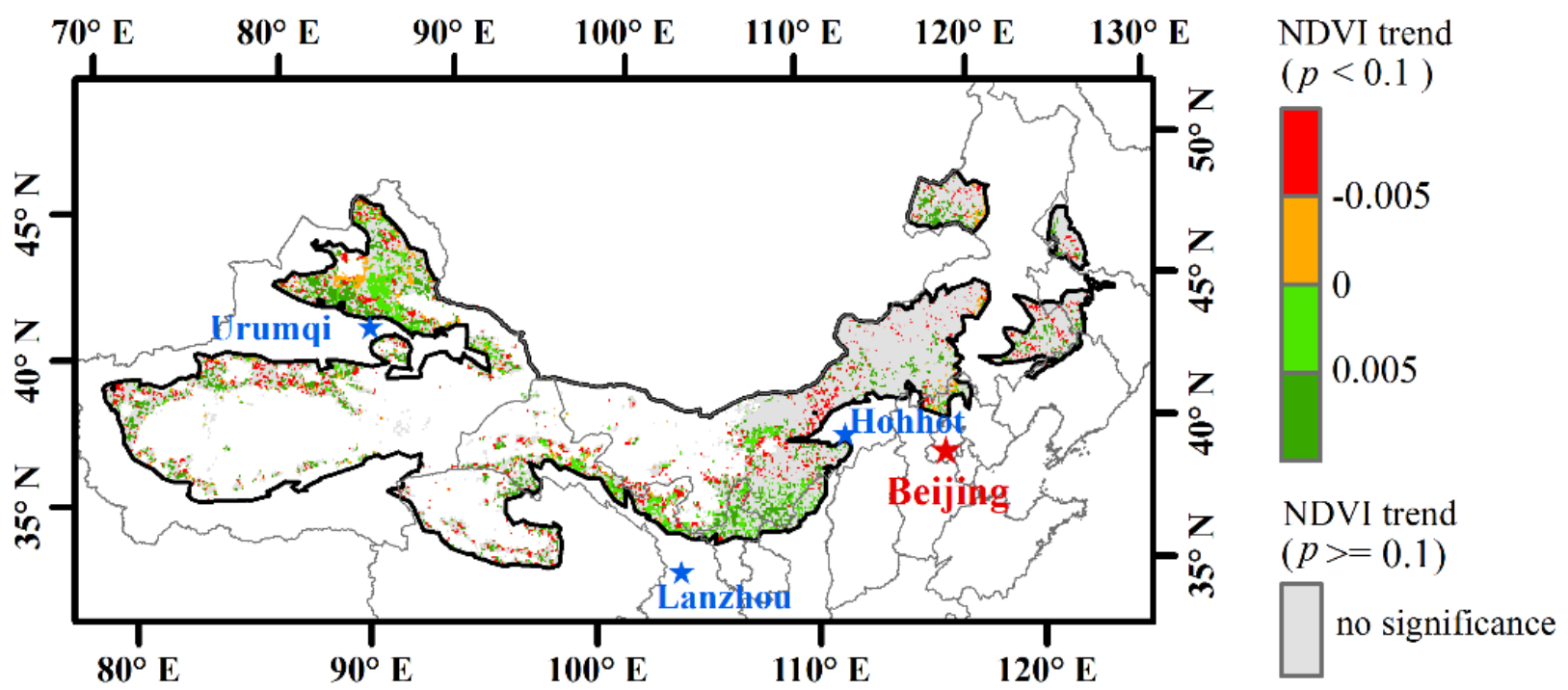

Figure 7: Spatial distribution of temporal trends in annual NDVI (1982-2013) for the greater desert belt (Fig. 1), based on linear regression. 
Biogeosciences Discuss., doi:10.5194/bg-2016-376, 2016

Manuscript under review for journal Biogeosciences

Published: 16 September 2016

(c) Author(s) 2016. CC-BY 3.0 License.

(c) (i)

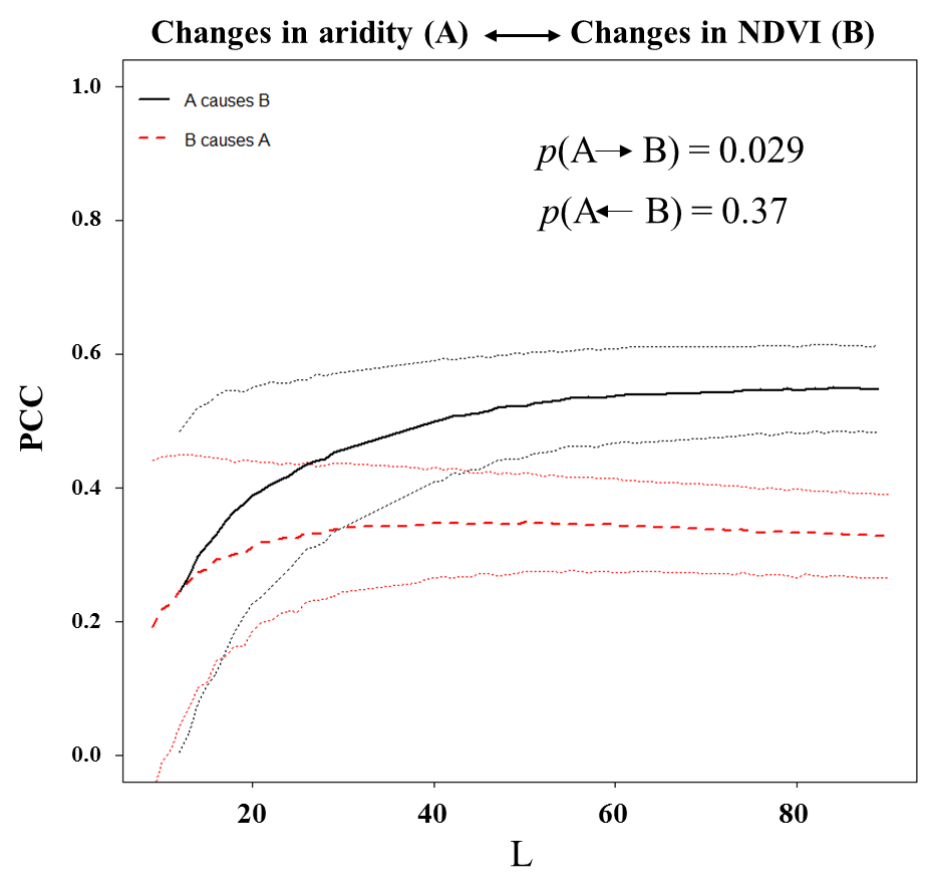

Figure 8: Curves of predictive skill based on Pearson's correlation coefficients (PCC) for convergent cross mapping (CCM) of aridity and normalized difference vegetation index (AI vs. NDVI) for several random points across the greater desert belt. Dotted lines on both sides of the solid and dashed curves (A causes B, black curve and B causes A, red dashed curve) of predictive skill give the standard error of estimate determined from bootstrapping, based on 5,000 iterations; CCM is implemented with procedures written in the $\mathbf{R}$ language (after Clark et al., 2015). The attribute that suggests causation is the convergence in the curve of predictive skill as timeseries record length $(\mathrm{L})$ is extended. Absence of convergence with low PCC indicates lack of causality among variables. Variables with the highest PCC at the point of convergence indicates the stronger controlling variable when feedback is identified. Analysis is based on embedded dimensions for both variables and time delays of 4 and 3, respectively (Sugihara et al., 2012). 
Biogeosciences Discuss., doi:10.5194/bg-2016-376, 2016

Manuscript under review for journal Biogeosciences

Published: 16 September 2016

(c) Author(s) 2016. CC-BY 3.0 License.

\section{Table}

Table 1. Trend analysis based on M-K tests and linear regression for precipitation, temperature, and AI for the twelve deserts.

\begin{tabular}{|c|c|c|c|c|c|c|}
\hline \multirow{2}{*}{ Desert } & \multicolumn{2}{|c|}{$P$} & \multicolumn{2}{|c|}{$T$} & \multicolumn{2}{|c|}{ AI } \\
\hline & $\begin{array}{c}\text { M-K } \\
\text { test }\end{array}$ & $\begin{array}{c}\text { slope } \\
\left(\mathrm{mm} \mathrm{yr}^{-1}\right)\end{array}$ & $\mathrm{M}-\mathrm{K}$ & $\begin{array}{c}\text { Slope } \\
\left(\mathrm{mm} \mathrm{yr}^{-1}\right)\end{array}$ & $\mathrm{M}-\mathrm{K}$ & $\begin{array}{l}\text { slope } \\
\left(\mathrm{yr}^{-1}\right)\end{array}$ \\
\hline Hulun Buir & -0.01 & -0.54 & $3.78^{* *}$ & 0.028 & -0.41 & -0.0008 \\
\hline Horqin & -1.61 & -0.88 & $3.65 * *$ & 0.032 & -0.86 & -0.0005 \\
\hline Otindag & -0.71 & -0.33 & $3.81 * *$ & 0.022 & -0.40 & -0.0002 \\
\hline Hobq & -0.24 & -0.17 & $5.18 * *$ & 0.082 & -0.28 & -0.0003 \\
\hline Mu Us & -0.11 & -0.35 & $2.84 * *$ & 0.025 & -0.15 & -0.0005 \\
\hline Ulanbuh & 0.40 & 0.15 & $2.57 * *$ & 0.013 & 0.41 & 0.0001 \\
\hline Tengger & 0.76 & 0.07 & $4.47 * *$ & 0.047 & -0.26 & -0.000014 \\
\hline Badain Jaran & 0.77 & 0.12 & $4.08 * *$ & 0.044 & 0.68 & 0.00001 \\
\hline Qaidam & 1.03 & 0.13 & $3.66 * *$ & 0.028 & $1.97 *$ & 0.0002 \\
\hline Kumtag & 0.84 & 0.05 & $2.91 * *$ & 0.025 & 1.20 & 0.00006 \\
\hline Gurbantunggut & $3.50 * *$ & 1.21 & $4.01 * *$ & 0.036 & $3.54 * *$ & 0.0013 \\
\hline Taklimakan & $1.82^{*}$ & 0.31 & $4.36 * *$ & 0.039 & $2.14 *$ & 0.0003 \\
\hline
\end{tabular}

* Indicate significance levels of $0.1, * 0.05 ; * * 0.01$. 